\title{
INTERVENSI PENGAYAAN PENGETAHUAN PANGAN DAN GIZI PADA MUATAN LOKAL UNTUK SEKOLAH MENENGAH PERTAMA DI KABUPATEN LAMPUNG BARAT
}

\author{
(Intervention of Enrichment of Food and Nutrition Knowledge in Local Content Course \\ for J unior High School In West Lampung Regency) \\ Sungkowo ${ }^{1}$, Budi Setiawan ${ }^{2}$, dan Siti Madanijah ${ }^{2}$ \\ ${ }^{1}$ Program Studi Manajemen Ketahahan Pangan (MKP), Sekolah Pascasarjana, IPB. \\ ${ }^{2}$ Departemen Gizi Masyarakat, Fakultas Ekologi Manusia (FEMA), IPB \\ Tel: 0251-8628304/8621258; Fax: 0251-8625846/8622276.
}

\begin{abstract}
ABST RACT
The problem in education especially in junior high school is low quality of education, caused by several factors such as social and economic situations. The purpose of the research was to study: 1) food and nutrition knowledge of the students; 2) food habit of the students; 3) ability to prepare traditional food of West Lampung; 4) nutritional status of students; 5) process of teaching and learning; and 6) Parent's support. The research was conducted at junior high school in Sukau in West Lampung Regency. The research used cluster random sampling technique, one class (VIII A) was chosen as control group and another (VIII C) as treatment group. There were significant differences between control and treatment class respectively: 1) the score of food and nutrition knowledge 12.89 and $15.03 ; 2$ ) the score of food habit 30.65 and $37.74 ; 3$ ) the level of preparing traditional food 24.03 and 27.56 ; 4) the process of teaching learning 34.39 and 38.90; and 5) parent's support 78.16 and 97.61 .
\end{abstract}

Keywords: intervention, nutrition knowledge, food habit.

\section{PENDAHULUAN}

Salah satu indikator kualitas sumber daya manusia adalah keadaan gizi yang baik, dimana kebutuhan dasar dapat tercukupi baik dari segi kualitas maupun kuantitasnya. Salah satu faktor yang mempengaruhi status gizi adalah pengetahuan pangan dan gizi, selain faktor kesediaan pangan. Sehingga diperlukan pendidikan gizi secara formal dan non formal.

Sasaran pendidikan gizi, tidak hanya kaum wanita yang meliputi ibu balita, wanita remaja dan wanita tua, melainkan juga anakanak sekolah. Upaya ini dimaksudkan sebagai salah satu cara untuk menyebarluaskan informasi tentang gizi kepada masyarakat terutama keluarga mereka sendiri. Sekolah dipandang mampu berperan sebagai "Agent of change" dalam pendidikan gizi.

Lembaga kesehatan dunia WHO menetapkan sasaran kegiatannya "Health For All By The Year 2010" dengan kata lain semua orang diharapkan dapat menjaga kesehatan dirinya dengan cara selalu mempraktekkan perilaku hidup sehat. Pangan dan gizi merupakan aspek penting bagi kesehatan yang perlu diketahui oleh semua kelompok usia. Oleh karena itu di sekolah perlu ada pelajaran yang memuat ma- teri pengetahuan pangan dan gizi atau menyisiplan materi pengetahuan pangan dan gizi pada berbagai mata pelajaran yang relevan.

Kurikulum pendidikan merupakan kerangka dasar pembentukan kompetensi yang diperlukan siswa. Dalam rangka meningkatkan kesadaran gizi di kalangan masyarakat luas, pemerintah juga telah memasukkan materi pendidikan gizi ke dalam Kurikulum Sekolah Menengah Pertama (SMP). Menurut Hidayat et al. (1998) bahwa pendidikan gizi di tingkat SMP ini telah disisipkan pada beberapa mata ajaran, diantaranya Olah Raga dan Kesehatan (Orkes), Ilmu Pengetahuan Alam (IPA), IImu Pengetahuan Sosial (IPS), Bahasa Indonesia, dan Agama.

Selain penyisipan materi gizi dalam beberapa bidang studi, ada faktor lain yang turut mempengaruhi keberhasilan pelaksanaan pendidikan gizi di SMP, antara lain kandungan materi dan metode penyajiannya. Dengan demikian perlu disusun model pengayaan yang harus diuji cobakan.

Muatan lokal (MULOK) merupakan kegiatan kurikuler untuk mengembangkan kompetensi yang disesuaikan dengan ciri khas dan potensi daerah, termasuk keunggulan daerah 
yang materinya tidak menjadi bagian dari mata pelajaran lain dan atau terlalu banyak sehingga harus menjadi mata pelajaran tersendiri sehingga harus dirumuskan metode intervensi dan pembelajaranya.

Kabupaten Lampung Barat merupakan salah satu daerah sentra penghasil sayur mayur, buah-buahan dan tanaman pangan lainnya, tetapi pelajaran MULOK tentang pertanian kurang menyentuh secara langsung pada aspek tersebut sehingga perlu diadakan peninjauan kembali pada pelajaran tersebut.

Penelitian ini bertujuan untuk menganalisis pengaruh intervensi pengayaan pengetahuan pangan dan gizi melalui mata pelajaran MULOK di bidang pertanian terhadap pengetahuan pangan dan gizi serta perilaku makan siswa.

\section{METODE PENELITIAN}

\section{Desain, Lokasi dan Waktu Penelitian}

Penelitian ini merupakan intervensi dengan melakukan pengayaan Pengetahuan $\mathrm{Pa}$ ngan dan Gizi pada mata pelajaran Muatan Lokal (MULOK). Penelitian diadakan di SMP Negeri 1 Sukau Kabupaten lampung Barat pada semester ganjil tahun pelajaran 2008 - 2009 yaitu.

\section{Tahapan-Tahapan Intervensi Pengayaan}

Tahapan intervensi pengayaan pengetahuan pangan dan gizi yang dilakukan adalah sebagai berikut:

1. Sosialisasi kepada seluruh tenaga pendidik (guru) baik yang bertugas mengajar pelajaran umum maupun guru yang bertugas mata pelajaran muatan lokal.

2. Menyiapkan pengajar untuk kelas penelitian dan kelas kontrol.

3. Menyiapkan materi model intervensi pengayaan pengetahuan pangan dan gizi untuk kelas perlakuan.

4. Menentukan metode pembelajaran dan waktu pelaksanaan selama 8 minggu dengan menggunakan metode ceramah, demonstrasi, diskusi, dan praktik.

5. Teknik pelaksanaan pembelajaran dikelas, mengacu pada model pengayaan yang telah disiapkan oleh peneliti pada kelas kelompok perlakuan.

6. Menenentukan kelas yang akan dijadikan model pengayaan pangan dan gizi menjadi kelas penelitian dan kelas kontrol.
7. Sosialisasi pengetahuan pangan dan gizi kepada orang tua yang dijadikan kelas penelitian.

8. Menyiapkan instrumen pre test dan Post test kelompok kontrol dan kelompok perlakuan.

9. Mengadakan pre test dan dilanjutkan dengan penilaian yang berkesinambungan pada kuesioner yang disiapkan peneliti selama pelaksanaan intervensi pengayaan Pengetahuan Pangan dan Gizi pada muatan pelajaran Mulok.

10. Pelaksanaan pengayaan selama 8 minggu pada kelas perlakuan.

11. Melakukan post testt yang akan digunakan untuk mengetahui pengaruh intervensi pengayaan pengetahuan pangan dan gizi pada kelompok kontrol dan kelompok perlakuan

\section{Cara Pengambilan Sampel}

Pengambilan sampel dilakukan dengan teknik cluster random sampling dari empat kelas yang dipilih secara acak dengan metode undian (Ridwan, 2004). Terambil 2 kelas secara acak; 1 kelas dipergunakan sebagai kelas kontrol diperoleh kelas VIII A sebagai kelas kontrol dan VIII C sebagai kelas perlakuan berjumlah 77. Sisanya untuk kelas VIII B dan VIII D Uji Coba berjumlah 80 .

\section{Jenis dan Cara Pengumpulan Data}

Data yang dikumpulkan dari penelitian ini adalah data primer dan data sekunder. Data primer diperoleh dari siswa, sedangkan data sekunder diperoleh dari sekolah mengenai gambaran singkat sekolah. Data pada pengetahuan pangan dan gizi diperoleh melalui sistem test, sedangkan pada pola konsumsi dan perilaku makan, sikap siswa terhadap PBM serta dukungan orang tua melalui kuisioner, sementara kemampuan menyiapkan makanan tradisional dinilai secara langsung oleh beberapa guru, Penimbangan dan pengukuran tinggi badan dilakukan oleh guru pembina UKS dan bantuan petugas PUSKESMAS. Data primer yang dikumpulkan :

1. Pengetahuan pangan dan gizi siswa sebelum dan sesudah intervensi pengayaan

2. perilaku makan siswa sebelum dan sesudah intervensi pengayaan

3. Kemampuan siswa dalam menyiapkan makanan khas lampung barat berdasarkan penilaian guru

4. Pengukuran status gizi dengan cara antropometri menggunakan indeks masa tubuh (IMT) dengan mengkur berat badan dan tinggi badan 
5. Penilaian siswa terhadap proses belajar mengajar materi intervensi pengayaan pangan dan gizi

6. Dukungan orang tua terhadap siswa

\section{Pengukuran Status Gizi}

Pengukuran status gizi secara antropometri menggunakan Indeks Masa Tubuh (IMT) dengan mencari berat badan dan tinggi badan.

$$
\mathrm{IMT}=\frac{\text { Berat Badan }(\mathrm{Kg})}{\text { Tinggi Badan }(\mathrm{m}) \times \mathrm{T} \text { Tinggi Badan }(\mathrm{m})}
$$

Klasifikasi Status Gizi yang dihitung dari IMT tersebut dibedakan menjadi Katagori yaitu : < 18.5 Status Gizi (Kurus), 18.5 - 25.0 Status Gizi (Normal), dan > 25.0 Status Gizi (Gemuk). (Kusharto dan Yayah, 2008)

\section{Pengolahan dan Analisis Data}

Pengolahan dan analisis data dilakukan dengan analisis secara deskriptif dan inferensia. Untuk mengetahui hubungan antar peubah penelitian digunakan uji statistik dengan menggunakan korelasi spearman untuk mengetahui kemampuan kognitif siswa terutama berkenaan dengan pengetahuan pangan dan gizi di semester ganjil, dimulainya proses belajarmengajar (PBM) dilakukan pre test dan di akhir PBM dilakukan post tes.

Bentuk pre test dan post test sebelum diberikan kepada para siswa terlebih dahulu didiskusikan oleh masing-masing guru mata pelajaran muatan lokal (mulok). Mengingat penelitian ini menggunakan metode pengayaan muatan pangan dan gizi sebagai patokan dalam pelaksanaannya, maka menurut Thoha (1991), digunakan pendekatan rasional yakni membandingkan butir soal dengan pokok bahasan, sub pokok bahasan dan aspek perilaku yang diukur. Reliabilitas test diujicobakan pada siswa yang sama sekali tidak ikut kegiatan penelitian, baik dari kelompok kontrol maupun kelompok perlakuan.

Pengetahuan pangan dan gizi pada con- toh dinilai dari hasil jawaban terhadap ber- bagai pertanyaan yang dibuat berdasarkan karakteristik pengetahuan pangan dan gizi, sebanyak 20 item; jika benar diberikan nilai 1 dan jika jawaban salah bernilai 0 .

Alternatif jawaban dari instrumen pengetahuan pangan dan gizi, perilaku makan dan proses belajar mengajar dilihat berdasarkan kecenderungan jawaban siswa untuk menyetujui atau menolak pernyataan yang mengandung karakteristik skala sikap dengan modifikasi dibuat dengan sekala penilaian:

Tabel 1. Katagori Penilaian Kuesioner

\begin{tabular}{ccc}
\hline No & Kategori & Skor \\
\hline 1 & Jawaban A & 3 \\
2 & Jawaban B & 2 \\
3 & Jawaban C & 1 \\
\hline
\end{tabular}

Untuk mengetahui perbedaan hasil dari pre test - post test dilakukan perhitungan statistik dengan uji beda pasangan 2 kelompok dengan Program SPSS versi 10.05 dengan rumus manual sebagai berikut:

$$
t=\frac{\overline{x_{1}}-\overline{x_{2}}}{s^{2} \sqrt{\frac{1}{n_{1}}}+\frac{1}{n_{2}}}
$$

\begin{tabular}{|c|c|c|}
\hline$x_{1}, X_{2}$ & $=$ & Rata-rata sampel \\
\hline$s^{2}$ & & Standar Deviasi \\
\hline $\mathrm{n}^{1}, \mathrm{n}_{2}$ & & Jumlah sampel \\
\hline
\end{tabular}

Keterangan :

Pemberian pengayaan pada proses belajar mengajar dilakukan di dalam kelas dengan berbagai metode mengajar (ceramah, demontrasi, pengenalan bahan makanan, pemilihan bahan makanan, persiapan bahan makanan dan pengolahan bahan makanan dan tata cara makan). Materi yang diberikan kepada siswa mengacu pada model pengayaan pengetahuan pangan dan gizi. Pengembangan program belajar diambil berdasarkan model pengetahuan pangan dan gizi.

Para siswa dalam dua kelas dianggap sebagai 2 kelompok yaitu kelompok perlakuan (VIIIC) dan kelompok kontrol (VIIIA), untuk mengetahui perbedaan hasil antara dua kelompok tersebut dapat juga digunakan rumus uji beda rata-rata 2 kelompok.

Kriteria yang digunakan dalam penelitian ini menggunakan $\mathrm{t}$ hitung yang diperoleh dari output program SPSS versi 10.05 dengan $t$ tabel pada sampel VIII $A=38$ dan VIII $C=39$, sehingga diperoleh $t$ tabel $(38+39)-2$. Terdapat perbedaan yang berarti antara kelompok kontrol dengan kelompok perlakuan jika $r_{\text {hit }}>$ $r_{\text {tabel }}$ dan menolak Ho jika $r_{\text {hit }}<r_{\text {tabel. }}$

Sebelum dilakukan pengujian lebih lanjut data yang diperoleh di uji persyaratan analisis yaitu normalitas dan homogenitasnya, sedangkan uji coba instrumen dilakukan sebelum instrumen digunakan sebagai penelitian. Kelas uji coba untuk kelompok kontrol dilakukan di 
kelas VIII B, sedangkan Uji coba instrumen untuk kelompok perlakuan disebarkan di kelas VIII D. Setelah data memenuhi syarat maka data di deskripsikan dalam bentuk tabel frekuensi dan histogram.

Uji coba instrumen penelitian dilakukan di kelas VIII B yang berjumlah 40 siswa dan VIII D berjumlah 40 siswa, sedangkan kelas perlakuan di lakukan pada 77 responden pada kelas VIII A dan VIII C.

\section{Uji Persyaratan Analisis}

Sebelum dilakukan pengujian lebih lanjut setelah mendapatkan data diadakan uji normalitas dan homogenitas. Pengujian dilakukan dengan program SPSS versi 10.05. Hasil rangkuman normalitas dan homogenitasnya seperti dibawah ini. Uji Normalitas menggunakan Uji Kolmogorov - Smirnov Test dengan kriteria yang digunakan adalah menolak hipotestis nol, apabila nilai Asymp sig (2 Tailed) < 0.05 yang berarti populasi tidak normal. Sebaliknya, jika nilai Asymp sig (2 Tailed) > 0.05 berarti populasi berdistribusi normal. Untuk lebih jelasnya dapat dilihat pada Tabel 2.

Berdasarkan pengujian SPSS dengan kriteria probabilitas $\geq 0.105$ dikatakan homogen sehingga dapat dikatakan bahwa varian y atas $x$ tersebut diatas homogen (Arif, 2001). Untuk lebih jelasnya dapat dilihat pada (Tabel 3).
Dari hasil pengolahan SPSS untuk normalitas dan homogenitas data untuk masingmasing variabel diatas memenuhi syarat untuk dilakukan pembahasan dan pengujian lebih lanjut.

\section{HASIL DAN PEMBAHASAN}

\section{Keadaan Umum Sekolah yang Diteliti}

Sekolah yang diteliti adalah Sekolah Menengah Pertama (SMP) Negeri 1 Sukau, Kecamatan Sukau, Kabupaten Lampung Barat. SMP Negeri 1 Sukau dipimpin oleh seorang Kepala Sekolah yang dibantu oleh satu wakil kepala sekolah dan empat wakil urusan kurikulum, kesiswaan, sarana prasarana, dan humas. SMP Negeri 1 Sukau memiliki 41 staf pengajar, dengan rincian seperti pada (Tabel 4).

Tabel 4. Sebaran Guru SMPN 1 Sukau menurut Tingkat Pendidikan

\begin{tabular}{|c|c|c|c|c|}
\hline \multirow{2}{*}{ No } & \multirow{2}{*}{ J abatan } & \multicolumn{2}{|c|}{ Pendidikan } & \multirow{2}{*}{ J umlah } \\
\hline & & D2/D3 & S1 & \\
\hline 1 & Kepala Sekolah & - & 1 & 1 \\
\hline 2 & Wakasek & - & 1 & 1 \\
\hline 3 & Guru Tetap/PNS & 4 & 31 & 35 \\
\hline \multirow[t]{2}{*}{4} & GTT/Guru Bantu & 1 & 3 & 4 \\
\hline & Total & 5 & 36 & 41 \\
\hline
\end{tabular}

Tabel 2. Pengujian Normalitas Data

\begin{tabular}{clccc}
\hline No & \multicolumn{1}{c}{ Variabel } & $\begin{array}{c}\text { Kolmogorov } \\
\text { Smirnov Test }\end{array}$ & $\begin{array}{c}\text { Asymp sig (2 } \\
\text { Tayled) }\end{array}$ & Kesimpulan \\
\hline 1 & Pengetahuan Pangan dan gizi & 0.742 & 0.871 & normal \\
2 & Kebiasaan makan & 0.461 & 0.735 & normal \\
3 & Kemampuan menyiapkan makan & 0.523 & 0.473 & normal \\
& Pengukuran Berat Badan dan tinggi badan & 0.542 & 0.964 & normal \\
& Proses PBM dan guru & 0.988 & 0.908 & normal \\
6 & Dukungan orang tua & 0.417 & 0.608 & normal \\
\hline
\end{tabular}

Tabel 3. Pengujian Homogenitas Data

\begin{tabular}{clcc}
\hline No & \multicolumn{1}{c}{ Variabel } & $\begin{array}{c}\text { Kolmogorov } \\
\text { Smirnov Test }\end{array}$ & Kesimpulan \\
\hline 1 & Pengetahuan Pangan dan gizi & 0.698 & Homogen \\
2 & Kebiasaan makan & 0.062 & Homogen \\
3 & Kemampuan menyiapkan makan & 0.149 & Homogen \\
& Pengukuran Berat Badan dan tinggi badan & 0.845 & Homogen \\
& Proses PBM dan guru & 0.971 & Homogen \\
6 & Dukungan orang tua & 0.174 & Homogen \\
\hline
\end{tabular}


Seluruh siswa SMP Negeri 1 Sukau berjumlah 467 siswa terdiri dari 12 rombongan belajar (rombel). Kelas VII 4 Kelas, Kelas VIII (4 Kelas), dan kelas IX (4 Kelas).

Tabel 5. Sebaran Siswa SMPN 1 Sukau menurut Kelas

\begin{tabular}{ccc}
\hline Kelas & J umlah Rombel & J umlah Siswa \\
\hline Kelas VII & 4 & 151 \\
Kelas VIII & 4 & 157 \\
Kelas IX & 4 & 159 \\
\hline Total & 12 & 467 \\
\hline
\end{tabular}

Sebagai Rintisan Sekolah Standar Nasional (SSN), SMP Negeri 1 Sukau dilengkapi fasilitas pendukung Kegiatan Belajar Mengajar (KBM) yaitu, ruang kelas kelas 1 sampai kelas III sebanyak 12 lokal ruang belajar, ruang guru, ruang tata usaha, ruang laboratorium, ruang perpustakaan, masjid, ruang ekstrakurikuler, kantin, dan kamar mandi/WC. Kegiatan sekolah di SMP Negeri 1 Sukau selain kegiatan belajar, juga menyediakan bebagai kegiatan ekstrakurikuler antara lain; Pramuka, PMR, ROHIS, Kesenian, dan Olahraga, guna mewadahi dan mengembangkan bakat, kreativitas, serta minat siswa untuk belajar.

Lokasi SMP Negeri 1 Sukau berada di Kabupaten Lampung Barat, Propinsi Lampung memiliki karakteristik daerah pegunungan dan sumber daya air yang berlimpah dan merupakan daerah penghubung serta perbatasan dengan propinsi yang ada di Sumatera. Daerah Sukau berada di daerah dataran tinggi dengan ketinggian dari permukaan laut kira-kira 9000 $m$ dengan luas wilayah 1800 ha dan jarak dari ibukota Kabupaten Lampung Barat $3 \mathrm{~km}$. Karakteristik khusus yang dimiliki Kabupaten Lampung Barat adalah udara yang dingin dan sejuk, memiliki sumber pangan misalnya sayur dan buah yang melimpah karena itu diproyeksikan sebagai sentra produksi sayur mayur dan tanaman pertanian kopi dan lada untuk propinsi Lampung.

\section{Gambaran Umum Siswa}

Keadaan umum siswa berjumlah 157 yang terdiri atas 4 kelas. Siswa yang dijadikan sampel sebanyak 77 orang pada kelas VIII (VIII A dan VIII C). Umur rata-rata yang dijadikan responden berada pada 13 - 14 tahun. Dari 77 Pelajar yang dijadikan responden dari kedua kelas memiliki 34 siswa responden laki-laki dan 43 siswa responden wanita.

\section{Pengetahuan Pangan dan Gizi Siswa}

Hasil penilaian terhadap jawaban siswa mengenai pengetahuan pangan dan gizi menunjukkan bahwa pada pengukuran awal, pengetahuan siswa mengenai pangan dan gizi termasuk kurang. Rata-rata skor pengetahuan siswa kedua kelompok relatif sama, yaitu 51.97 pada kelompok kontrol dan 51.92 pada kelompok perlakuan, yang secara statistik tidak berbeda nyata. Dengan adanya pengayaan materi mengenai pangan dan gizi pada kelompok perlakuan, terdapat peningkatan yang cukup signifikan, yaitu menjadi 75.13 dibanding 64.47 pada kelompok kontrol (Tabel 6).

Peningkatan pengetahuan pangan dan gizi pada kelas kontrol tertinggi terdapat pada aspek fungsi zat gizi sebesar 13.53 atau $26.1 \%$, hal ini juga terjadi pada kelas perlakuan sebesar 28.21 atau 53.5\% . Hal ini dikarenakan aspek fungsi zat gizi telah disisipkan pada salah satu mata pelajaran IPA.

Peningkatan pengetahuan siswa sebesar 23.21 atau $44.7 \%$ pada kelompok perlakuan dan 12.50 atau $24.0 \%$ pada kelompok kontrol berbeda nyata secara statistik ( $p>0.05)$. Rata-rata skor pengetahuan pada siswa kelompok kontrol yang juga sedikit meningkat, diduga disebabkan adanya windows effect, yaitu adanya bias atau pengaruh antar teman.

Tabel 6 juga menunjukkan adanya keragaman pengetahuan siswa pada setiap aspek pengetahuan pangan dan gizi. Pada kelas kontrol aspek konsep dasar gizi, pengetahuan siswa akan aspek ini menunjukan nilai 51.32 yang berarti hanya 20 orang yang tahu akan aspek ini. Hal ini tidak jauh berbeda dengan kelas perlakuan hanya 22 dari 39 responden yang mengetahui (54.49) akan aspek konsep dasar gizi. Setelah post-test kelas kontrol untuk aspek konsep dasar gizi menunjukan nilai

Tabel 6. Perbedaan Tingkat Pengetahuan Pangan dan Gizi

\begin{tabular}{llcccccc}
\hline \multirow{2}{*}{ No } & \multirow{2}{*}{ Aspek } & \multicolumn{3}{c}{ Kontrol } & \multicolumn{3}{c}{ Perlakuan } \\
\cline { 3 - 7 } & & Pre-test & Post-test & $\delta$ & Pre-test & Post-test & $\delta$ \\
\hline 1 & Konsep Dasar Gizi & 51.32 & 61.84 & 10.52 & 54.49 & 73.72 & 19.23 \\
2 & Klasifikasi Pangan dan Gizi & 52.34 & 64.91 & 12.57 & 50.14 & 71.23 & 21.08 \\
3 & Fungsi Zat Gizi & 51.88 & 65.41 & 13.53 & 52.75 & 80.95 & 28.21 \\
& Keseluruhan & 51.97 & 64.47 & 12.50 & 51.92 & 75.13 & 23.21 \\
\hline
\end{tabular}


61.84 atau hanya 24 orang dari 38 orang yang mengetahui. Sedangkan pada kelas perlakuan sekitar 28 orang dari 39 orang (73.72) yang mengetahui aspek konsep dasar gizi.

Pada aspek klasifikasi pangan dan gizi, pengetahuan siswa akan aspek ini juga beragam. Pada kelas kontrol dan kelas perlakuan untuk pre-test dan post-test terlihat keberagaman yang hampir sama dengan aspek konsep pangan dan gizi. Pada aspek fungsi zat gizi keragaman yang juga hampir sama, namun pada kelas perlakuan setelah post-test peningkatan terjadi sebesar 28.21 atau $53.48 \%$.

Walaupun ada peningkatan yang cukup nyata pada kelompok perlakuan, namun hampir $50 \%$ siswa mempunyai tingkat pengetahuan termasuk kategori cukup, bahkan masih ada $10 \%$ siswa yang termasuk kurang. Hal ini menunjukkan masih perlunya ditingkatkan pengayaan pengetahuan secara lebih intensif. Sebaran siswa menurut tingkat pengetahuan pangan dan gizi kedua kelompok dapat dilihat pada Tabel 7.

Tabel 7. Sebaran Siswa menurut Tingkat Pengetahuan Pangan dan Gizi Sebelum dan Setelah Intervensi

\begin{tabular}{llcccccccc}
\hline & & \multicolumn{4}{c}{ Kontrol } & \multicolumn{3}{c}{ Perlakuan } \\
\cline { 3 - 10 } No Kategori & Pre-test & Post-test & \multicolumn{1}{c}{ Pre-test } & Post-test \\
\cline { 3 - 10 } & & $\mathbf{n}$ & $\%$ & $\mathbf{n}$ & $\%$ & $\mathbf{n}$ & $\%$ & $\mathbf{n}$ & $\%$ \\
\hline 1 & Baik & 2 & 5.3 & 6 & 15.8 & 0 & 0.0 & 12 & 30.8 \\
2 & Sedang & 7 & 18.4 & 19 & 50.0 & 13 & 33.3 & 23 & 59.0 \\
3 & Kurang & 29 & 76.3 & 13 & 34.2 & 26 & 66.7 & 4 & 10.3 \\
& Jumlah & 38 & 100 & 38 & 100 & 39 & 100 & 39 & 100 \\
\hline
\end{tabular}

Pengujian dilakukan dengan membandingkan rata-rata hasil post-test setelah intervensi antara kelas kontrol dengan kelas perlakuan ternyata setelah diuji dengan uji t untuk pengetahuan pangan dan Gizi diperoleh $\mathrm{t}$ hitung sebesar 3.489 dan $\mathrm{t}$ tabel 1.98 artinya bahwa terdapat perbedaan yang signifikan antara kelas kontrol dan kelas perlakuan.

Hasil yang didapatkan dalam penerapan intervensi pengayaan pengetahuan pangan dan gizi dalam studi pengayaan dari berbagai variabel sudah mempunyai pengaruh yang baik, selain mampu memberi semangat dalam belajar secara otomatis dan memiliki pengetahuan yang lebih baik dibandingkan sebelum adanya pengayaan. Sebagai contoh dapat dilakukan dengan pengenalan pangan dan gizi dan konsep bagaimana cara menyiapkan makanan, membuat, menyajikan dan menghidangkan sesuai dengan kebutuhan untuk kebutuhan dirinya dan kebutuhan bagi keluarganya yang dimulai dengan mempelajari makanan tradisional khas Lampung khususnya Lampung Barat. Pengetahuan tentang pola makan dan status gizi dalam diri siswa juga semakin meningkat baik dari frekuensi maupun kesadaran tentang nilai gizi yang terkandung dalam makanan tersebut.

Intervensi pengayaan pengetahuan pangan dan gizi yang dilakukan pada kelas perlakuan seara rata-rata menunjukan perbedaan dibandingkan kelas kontrol sehingga dapat ditarik kesimpulan bahwa dengan diberikannya intervensi pengayaan ini mampu meningkatkan pengetahuan tentang pangan dan gizi itu sendiri. Penelitian ini sudah sesuai dengan beberapa teori antara lain menurut kurikulum 2005 pelaksanaan pendidikan gizi dintevensikan ke dalam bidang studi Orkes, IPA, Muatan Lokal serta melalui Program Usaha Kesehatan Sekolah (UKS). Melalui program UKS, murid SMP mendapatkan pendidikan gizi praktis yang berupa penangulangan penyakit-penyakit akibat kekurangan gizi, pembinaan warung sekolah dan kebun sekolah. Kegiatan ini dimaksudkan untuk menyebarluaskan pengetahuan gizi, meningkatkan kemampuan Guru, murid serta orang tuanya dalam upaya memperbaiki gizi anak sekolah dan masyarakat (Departemen Kesehatan RI, 1984)

Pengetahuan tentang gizi dapat diartikan sebagai upaya membuat seseorang atau sekelompok masyarakat mengerti akan pentingnya gizi. Melalui pendidikan gizi diharapkan pengetahuan seseorang mengenai gizi dan makanan sehat menjadi lebih baik, yang pada gilirannya dapat memperbaiki status gizi masyarakat (Tarwotjo, 1981).

Menururt Harper dkk (1985) pendidikan pangan dan gizi adalah suatu proses belajar mengajar tentang pangan, bagaimana tubuh menggunakannya dan mengapa pangan diperlukan untuk kesehatan. Pendidikan gizi mempunyai tujuan akhir mengubah pengetahuan, sikap, dan keterampilan ke arah perbaikan gizi yang diharapkan. Selanjutnya dikemukakan pula bahwa pendidikan gizi merupakan hal yang penting dan mutlak harus dimasukkan sebagai bagian dari kebijakan gizi dalam pembangunan nasional. Pendidikan gizi harus menjadi bagian internal dari pendidikan formal mulai dari tingkat sekolah menengah sampai perguruan tinggi. Zeitlin (1977) mengemukakan bahwa karakteristik pendidikan gizi mengikuti prinsip P-S-K (Pengetahuan - Sikap - Keterampilan), dengan asumsi bahwa perubahan pengetahuan akan membawa perubahan terhadap sikap dan selanjutnya akan mengakibatkan perubahan 
pada keteramilan atau kebiasaan makan. Diharapkan hal ini juga terjadi pada muridmurid SMP.

Murid pada tingkat pertama perlu diberikan pengetahuan untuk memilih dan makan yang bervariasi agar pertumbuhan badan serta kesehatan dapat terjamin. Dengan demikian setelah menguasai pengetahuan tersebut, murid akan senantiasa menjaga kesehatan dan status gizinya, memiliki kebiasaan makan yang baik, bersikap positif terhadap pangan-pangan gizi, mempunyai keterampilan gizi serta mampu berperan sebagai "agent of change" terhadap kebiasaan makan keluarganya (Critchie, 1973). Anak usia sekolah dapat digambarkan sebagai anak berumur 6 sampai 12 tahun, dengan karakteristik masa pertumbuhan yang relatif tetap dan dengan sedikit masalah pemberian makan.

Pada masa ini terjadi peningkatan nafsu makan secara alamiah, sebuah faktor yang dapat meningkatkan konsumsi makanan. Waktu lebih banyak dihabiskan di sekolah sehingga anak usia ini mulai menyesuaikan diri dengan jadwal rutin. Mereka juga mencoba mempelajari keterampilan fisik dan menghabiskan waktu untuk bermain. Di sekolah juga mempelajari tentang makanan dan gizi sebagai bagian dari kurikulum sekolah. Pengaruh teman sebaya, guru, pelatih dan tokoh idola sangat besar.

Anak usia sekolah ini tumbuh dengan kecepatan genetis masing-masing, dengan perbedaan tinggi badan yang sudah mulai tampak. Ada sebagian anak yang terlihat relatif lebih pendek atau tinggi. Atau, pertumbuhannya lebih lambat dibandingkan dengan teman-teman sebayanya. Walaupun jarang terjadi masalah pemberian makan, namun bukan berarti tidak ada masalah makan dan gizi pada anak usia ini. Masalah akan yang tidak terselesaikan pada usia balita dapat berlanjut ke masa usia sekolah,dan bisa mengakibatkan timbulnya masalah gizi. Dalam hal ini sebagai contoh dapat dilakukan dengan pengenalan pangan dan gizi dan konsep bagaimana cara mengonsep makanan, membuat, menyajikan dan menghidangkan sesuai dengan kebutuhan untuk kebutuhan dirinya dan kebutuhan bagi keluarganya yang dimulai dengan mempelajari makanan tradisional khas Lampung khususnya lampung Barat, jadi dengan adanya intervensi pengayaan memungkinkan terjadinya perbedaan yang signifikan antara kelas kontrol dan kelas perlakuan sehingga siswa kelas perlakuan dapat dianggap memiliki pengetahuan tentang pangan dan gizi secara lebih baik.

\section{Perilaku Makan Siswa}

Sebelum digunakan untuk penelitian, instrumen perilaku makan diuji coba terlebih dahulu pada kelas VIIIB dan VIIID. Pengujian dilakukan untuk melihat validitas dan reliabilitas instrumen dari 2 nilai pada kelas yang berbeda. Hasil dari pengujian menunjukan terdapat 21 instrumen yang valid dengan koefisien reliabilitas 0.677 , sehingga instrumen perilaku makan siswa layak digunakan untuk penelitian.

Nilai rata-rata skor perilaku makan siswa kelas perlakuan (9.71) secara nyata lebih tinggi dibanding rata-rata skor kelas kontrol (2.54). Dengan demikian terjadi peningkatan yang signifikan sebesar 7.17. Untuk lebih jelasnya dapat dilihat pada tabel 8 .

Tabel 8. Perilaku makan siswa

\begin{tabular}{ccccccccc}
\hline & & \multicolumn{3}{c}{ Kelas Kontrol } & \multicolumn{3}{c}{ Kelas Perlakuan } \\
\cline { 3 - 8 } No & Aspek & $\begin{array}{c}\text { Pre- } \\
\text { test }\end{array}$ & $\begin{array}{c}\text { Post- } \\
\text { test }\end{array}$ & $\delta$ & $\begin{array}{c}\text { Pre- } \\
\text { test }\end{array}$ & $\begin{array}{c}\text { Post- } \\
\text { test }\end{array}$ & $\delta$ \\
\hline 1 & $\begin{array}{c}\text { Kebiasaan } \\
\text { Makan }\end{array}$ & 10.76 & 11.45 & 0.69 & 11.05 & 13.85 & 2.80 \\
2 & $\begin{array}{c}\text { Frekuensi } \\
\text { Makan }\end{array}$ & 5.21 & 5.13 & -0.08 & 5.15 & 8.59 & 3.44 \\
3 & $\begin{array}{c}\text { Tata Cara } \\
\text { Makan }\end{array}$ & 7.82 & 9.13 & 1.31 & 7.26 & 10.56 & 3.30 \\
4 & $\begin{array}{c}\text { Pantangan } \\
\text { Makan }\end{array}$ & 4.32 & 4.92 & 0.60 & 4.13 & 4.10 & -0.03 \\
\hline & Total & 28.11 & 30.65 & 2.54 & 28.03 & 37.74 & 9.71 \\
\hline
\end{tabular}

Pengujian dilakukan dengan membandingkan rata-rata hasil post-test setelah intervensi antara kelas kontrol dengan kelas perlakuan ternyata setelah diuji dengan uji t untuk perilaku makan diperoleh $t$ hitung sebesar 11.256 dan t tabel 1.98 artinya bahwa terdapat perbedaan yang signifikan antara kelas kontrol dan kelas perlakuan.

Faktor yang lain yaitu pada pola konsumsi tentang pantangan makan, walaupun anak tersebut sudah diberikan pengayaan tetapi justru tidak mengalami perbedaan, hal ini siswa yang alergi terhadap makanan tertentu misalnya udang akan berusaha menghindari makanan tersebut walaupun dia tahu bahwa hal tersebut bermanfaat bagi kesehatan dirinya dan sudah tahu tentang kandungan gizinya.

Dalam hubungannya dengan perubahan perilaku makan, pendidikan gizi sangat diperlukan, karena dapat membentuk sikap mental dan perilaku positif terhadap gizi. Menurut Critchie (1973) kebiasaan makan sangat dipengaruhi oleh tiga hal yaitu (1) perubahan lingkungan (2) Penerimaan/penolakan individu terhadap makan dan (3) perubahan makanan. 
Perubahan individu lebih banyak diupayakan lewat pendidikan.

Dari rata-rata dan pengujian uji t diperoleh bahwa terdapat perbedaan yang signifikan antara kelas kontrol dengan kelas perlakuan, dimana kelas perlakuan memiliki perilaku makan yang lebih baik dilihat dari kebiasaan, frekuensi dan ragamnya.

\section{Kemampuan Siswa Menyiapkan Makanan} Tradisional

Sebelum digunakan instrumen untuk penelitian instrumen kemampuan menyiapkan makan diuji coba pada kelas VIIIB dan VIIID untuk validitasnya. Pengujian dilakukan untuk melihat validitas dari 2 nilai pada kelas yang berbeda. Hasil dari pengujian menunjukan terdapat 10 instrumen yang valid, sedangkan koefisien reliabilitas tidak diuji karena praktek karena praktek menyiapkan makan hanya dilakukan 1 kali.

Nilai rata-rata skor kemampuan siswa menyiapkan makanan tradisional kelas perlakuan (6.67) secara nyata lebih tinggi dibanding nilai rata-rata skor kelas kontrol (3.61). Dengan demikian terjadi peningkatan yang signifikan yaitu sebesar 3.06, dengan demikian sementara dapat dilihat perbedaannya walaupun perbedaannya kecil. Untuk lebih jelasnya dapat dilihat pada tabel 9.

Tabel 9. Kemampuan Siswa menyiapkan Makanan tradisional

\begin{tabular}{llllllll}
\hline \multirow{2}{*}{ No } & \multicolumn{1}{c}{ Aspek } & \multicolumn{3}{c}{ Kontrol } & \multicolumn{3}{c}{ Perlakuan } \\
\cline { 2 - 7 } & $\begin{array}{l}\text { Pre- } \\
\text { test }\end{array}$ & $\begin{array}{c}\text { Post- } \\
\text { test }\end{array}$ & $\delta$ & $\begin{array}{c}\text { Pre- } \\
\text { test }\end{array}$ & $\begin{array}{c}\text { Post- } \\
\text { test }\end{array}$ & $\delta$ \\
\hline $\begin{array}{l}\text { Menyiapkan } \\
\text { Bahan }\end{array}$ & 6.95 & 7.18 & 0.23 & 7.71 & 8.23 & 0.52 \\
& $\begin{array}{l}\text { Cara } \\
\text { Mengolah }\end{array}$ & 6.00 & 6.72 & 0.72 & 5.97 & 8.86 & 2.89 \\
& $\begin{array}{l}\text { Cara } \\
\text { Menyajikan }\end{array}$ & 7.47 & 9.69 & 2.22 & 7.21 & 10.18 & 2.97 \\
\hline & 20.42 & 24.03 & 3.61 & 20.89 & 27.56 & 6.67 \\
\hline
\end{tabular}

Pada kemampuan siswa menyiapkan makanan tradisional kelas kontrol terjadi peningkatan 0.23 pada menyiapkan bahan makanan, pada cara mengolah 0.72 ; pada menyajikan 2.22; sedangkan pada kelas perlakuan terjadi peningkatan pada menyiapkan bahan sebesar 0.52; cara mengolah sebesar 2.89; cara menyajikan sebesar 2.97; dari nilai post-test terjadi perbedaan antara pre test dan post-test sebesar 0.29; cara mengolah 2.17 dan cara menyajikan 0.75 .
Sedangkan rata-rata secara keseluruhan menyiapkan makanan tradisional pada kelas kontrol 24.03 - 20.42 yaitu 3.61 dan pada kelas perlakuan 27.56 - 20.89 sehingga terdapat selisih 6.67. Perbedaan antara kelas kontrol dan kelas perlakuan sebesar 3.06. Hal tersebut penting dengan bertambahnya kemampuan menyiapkan yang terdiri dari mempersiapkan bahan bahan dasar baik dari bumbu dapat menyiapkan secara proporsional, dapat memilih bahan dasar yang masih segar baik bahan sayuran maupun bahan lain seperti daging, ikan dan lain-lain. Hal yang kedua adalah proses persiapan mengolah siswa mempunyai ketrrampilan untuk membersihkan, mengolahnya, Terakhir yang paling penting adalah penyajian, siswa harus mampu menyajikan secara baik sehingga mampu mengguggah selera makan, proporsi mampu disajikan secara tepat sehingga tidak mubazir jika ada makanan sisa misalnya mampu memperkirakan bahan yang diperlukan untuk 5 porsi.

Rasa dan aroma juga sangat penting dikuasai siswa dengan hal tersebut makanan mampu di jual selain di makan sendiri sehingga kemampuan menyiapkan makanan tradisional siswa akan dapat diaplikasikan di keluarga dalam upaya ikut memperkuat sistem ketahanan pangan khususnya makanan tradisional Lampung Barat.

Pengujian uji t yang dilakukan dengan membandingkan rata-rata hasil post-tes setelah intervensi antara kelas kontrol dengan kelas perlakuan ternyata kemampuan menyiapkan makan tradisional diperoleh $\mathrm{t}$ hitung sebesar 7.343 dan t tabel 1.98 artinya bahwa terdapat perbedaan yang signifikan antara kelas kontrol dan kelas perlakuan.

\section{Pengukuran Status Gizi}

Sebelum digunakan instrumen untuk penelitian status gizi tidak diuji coba karena pengukuran tinggi badan dan berat badan dilakukan pihak puskesmas dan UKS secara langsung yang tingkat akurasi datanya sudah cukup baik.

Tabel 10. Pengukuran Berat Badan dan Tinggi Badan (status gizi dengan IMT)

\begin{tabular}{cccccc}
\hline \multirow{2}{*}{ No } & Indikator & \multicolumn{2}{c}{ Kontrol } & \multicolumn{2}{c}{ Perlakuan } \\
\cline { 3 - 6 } & & Sebelum & Sesudah & Sebelum & Sesudah \\
\cline { 2 - 5 } & Penelitian & Penelitian & Penelitian & Penelitian \\
\hline 1 & $\begin{array}{l}\text { Berat badan } \\
(\mathrm{kg})\end{array}$ & 42.5 & 42.6 & 43.3 & 44.0 \\
$2 \begin{array}{l}\text { Tinggi badan } \\
(\mathrm{cm})\end{array}$ & 130.7 & 130.8 & 130.8 & 131.0 \\
\hline & 24.8 & 24.8 & 25.3 & 25.6 \\
\hline
\end{tabular}


Dari hasil gambaran di atas ternyata bahwa kelas kontrol cenderung normal dan untuk kelas perlakuan normal cenderung gemuk Pada pengukuran berat badan kelas kontrol terdapat selisih 0.12 dan tinggi badan 0.11 . Walaupun secara rata-rata terdapat perbedaan, tetapi setelah diadakan pengujian dengan uji t. perbedaan tersebut tidak nyata, artinya sangat kecil. Hal ini wajar karena dengan selang waktu pengukuran 2 bulan faktor tinggi dan berat badan belum memungkinkan untuk terjadi perbedaan yang signifikan. Pada berat badan badan sebesar 0.67 dan tinggi badan pada kelas perlakuan sebesar 0.22 . Pada berat badan justru terjadi penurunan dari 0.22 ke 0.67 artinya ada selisih 0.45 sedangkan pada tinggi badan ada kenaikan pada kelas kontrol dan kelas perlakuan sebesar 0.11 . Penambahan tinggi badan dan berat badan selama dua bulan belum tentu terjadi peningkatan yang signifikan hal ini dimungkinkan karena adanya siswa, sakit, walaupun tumbuh kesadaran tentang pola makan misalnya sarapan tetapi jika secara ekonomi belum memungkinkan maka hal tersebut belum dapat dilakukan. Untuk berat dan tinggi badan secara hasil pengujian tidak ada perbedaan secara nyata walaupun secara rata-rata dua kelompok tersebut berbeda.

Pengujian dilakukan dengan membandingkan rata-rata hasil post-test setelah intervensi antara kelas kontrol dengan kelas perlakuan ternyata setelah diuji dengan uji $t$ untuk menghitung berat badan dan tinggi badan diperoleh t hitung sebesar 0.843 dan $1.33 \mathrm{se}$ dangkan $t$ tabel 1.98 artinya bahwa tidak terdapat perbedaan yang signifikan antara kelas kontrol dan kelas perlakuan.

Variabel yang tidak mengalami perbedaan yang nyata dalam penelitian ini adalah pada faktor tinggi badan dan berat badan, hal ini wajar karena faktor tersebut di pengaruhi oleh banyak hal misalnya tingkat pendapatan dan ekonomi orang tua, faktor genetika, di luar waktu penelitian yang cukup sempit jadi penambahan berat badan dan tinggi badan belum dapat diukur seara nyata.

Faktor lain yang perlu dipertimbangkan adalah faktor waktu penelitian yang cukup singkat mengingat keterbatasan waktu sehingga perlu kajian lebih lanjut waktu ideal yang diperlukan untuk melihat tingkat pengayaan hubungannya dengan berat badan dan tinggi badan. Perbedaan yang tidak signifikan pada perbedaan rata-rata diatas adalah pada faktor tinggi badan dan berat badan, serta faktor pola makan pada sub indikator pantangan makan.

\section{Pelaksanaan Proses Belajar Mengajar}

Sebelum digunakan instrumen untuk penelitian instrumen proses belajar mengajar diuji coba pada kelas VIIIB dan VIIID. Pengujian dilakukan untuk melihat validitas dan realibilitas instrumen dari 2 nilai pada kelas yang berbeda. Hasil dari pengujian menunjukan terdapat 15 item instrumen yang valid dengan koefisien reliabilitas 0.923 , artinya instrumen tersebut layak dipergunakan untuk mendapatkan data.

Tabel 11. Pengukuran Pelaksanaan Proses Belajar Mengajar

\begin{tabular}{rrrcccccc}
\hline & & \multicolumn{3}{c}{ Kontrol } & \multicolumn{4}{c}{ Perlakuan } \\
\cline { 3 - 8 } No & Aspek & & $\begin{array}{c}\text { Pre- } \\
\text { test }\end{array}$ & $\begin{array}{c}\text { Post- } \\
\text { test }\end{array}$ & $\delta$ & $\begin{array}{c}\text { Pre- } \\
\text { test }\end{array}$ & $\begin{array}{c}\text { Post- } \\
\text { test }\end{array}$ & $\delta$ \\
\hline 1 & Materi & 17.63 & 18.35 & 0.72 & 17.52 & 20.35 & 2.83 \\
2 & Metode & 15.00 & 16.04 & 1.04 & 15.04 & 18.55 & 3.51 \\
& Total & 32.63 & 34.39 & 1.76 & 32.56 & 38.90 & 6.34 \\
\hline
\end{tabular}

Siswa pada proses belajar mengajar baik pada proses dalam kelas, pada pelajarannya maupun pada gurunya terjadi kenaikan pada kelas kontrol sebesar 1.76 sedangkan pada kelas perlakuan meningkat sebesar 6.34. Perbedaan kegiatan PBM dan guru dengan melihat sikap siswa secara umum terdapat perbedaan 4.58. Perihal tersebut terjadi peningkatan dalam hal guru memberikan kesempatan bertanya, teguran guru, teknik mengajar yang lebih menarik, penggunakan alat peraga, guru memeriksa buku LKS atau latihan, guru menyampaikan silabus, sistem pemeriksaan ulangan dimana hasil ulangan harus diperiksa secepatnya sehingga siswa, guru dan orang tua dapat memantau perkembangan pengetahuannya.

Pengujian dilakukan dengan membandingkan rata-rata hasil post-test setelah intervensi antara kelas kontrol dengan kelas perlakuan ternyata setelah diuji dengan uji t untuk proses belajar mengajar oleh guru diperoleh t hitung sebesar 4.183 dan $\mathrm{t}$ tabel 1.98 artinya bahwa tidak terdapat perbedaan yang signifikan antara kelas kontrol dan kelas perlakuan.

Pola pembelajaran dari hasil penerapan studi pengayaan sangat tergantung dari metode pengenalan dan penerapan pengetahuan pangan dan gizi dari hasil pola belajar di dalam kelas. Guru yang dapat memberikan proses pengayaan secara baik akan dapat meningkatkan semangat belajar yang tidak dida- 
patkan sebelum materi pengetahuan pangan disajikan dalam intervensi ke dalam mata pelajaran. Penyampaian dengan media dan menarik sangat diperlukan selain kedalaman materi itu sendiri. Jika guru mampu memberikan proses tersebut seara menarik pada kelas pengayaan maka akan dimungkinkan terjadi peningkatan akhir yang diharapkan yaitu peningkatan pengetahuan siswa mengenai pengetahuan dan gizi. Beberapa hal yang terlibat dalam belajar mengajar meliputi siswa, guru, proses, sarana berupa modul atau materi, dan cara penyampaian materi, dimungkinkan sistem pembelajaran pada kelas perlakuan berlangsung seara baik.

Dari berbagai penelitian yang telah dilakukan terhadap anak-anak SMP masih banyak ditemukan adanya masalah kekurangan gizi pada anak-anak usia SMP sehingga perlu diupayakan perbaikan gizi anak sekolah dilaksanakan melalui kurikulum SMP yakni dengan Pengayaan Gizi Praktis di sekolah.

Teknik intervensi pengayaan yang baik dan menyelesaikan masalah yang terjadi pada penyampaian materi pangan dan gizi perlu adanya pola kerjasama yang sesuai dengan teknik mendidik, teknik mendidik/pendidikan materi, tujuan, metode yang dipakai, materi yang akan disampaikan, karakeristik sasaran, media, pameran, demonstrasi, perlombaan, kunjung lapang, dan tutorial.

Dari hasil penelitian semua faktor dapat meningkat dengan adanya intervensi pengayaan yang dilakukan, hal tersebut dapat dilihat dari kenaikan skor masing-masing indikator. Secara detail hal tersebut dapat dilihat perbedaan antara dua rata-rata pada kelompok kontrol dan kelompok perlakuan.

Pertimbangan lain yang perlu diperhatikan dalam proses belajar mengajar dalam memahami studi pengayaan sebagai berikut: 1) materi harus relevan dan ada keterkaitan antara materi dan kondisi situasi belajar; 2) partisipasi dan aktif antara pengajar dan pelajar; 3) keterlibatan mental dan emosi; 4) pelajar bebas memilih materi yang akan disajikan; 5) Keberhasilan pengalaman baik pelajar dan pengajar akan menentukan dan memberikan motivasi selanjutnya; 6) disenangi oleh pelajar; 7) materi, metode, dan teknik disusun untuk menumbuhkan kemandirian sasaran; 8) kegunaannya tepat; 9) sikap yang positif dalam menerima dan menyetujui kegunaan materi tersebut; dan 10) penemuan akan memberikan kepuasan terhadap materi yang disajikan.

\section{Dukungan Orang Tua terhadap Siswa}

Sebelum digunakan instrumen untuk penelitian instrumen dukungan orang tua diuji coba pada kelas VIIIB dan VIIID. Pengujian dilakukan untuk melihat validitas dan reliabilitas instrumen dari 2 nilai pada kelas yang berbeda. Hasil dari pengujian menunjukan terdapat 35 item instrumen yang valid dengan koefisien reliabilitas 0.749 artinya instrumen tersebut layak dipergunakan untuk mendapatkan data.

Nilai rata-rata skor dukungan orang tua kelas perlakuan (20.66) secara nyata lebih tinggi dibandingkan nilai rata-rata skor kelas kontrol (1.13). Dengan demikian terjadi peningkatan yaitu sebesar 19.53. Gambaran sementara bahwa kelas perlakuan memiliki ratarata tentang dukungan orang tua secara lebih baik dibandingkan dengan kelas kontrol, lebih jelasnya dapat dilihat pada (Tabel 13).

Tabel 13. Pengukuran Dukungan Orang Tua terhadap Siswa

\begin{tabular}{|c|c|c|c|c|c|c|c|}
\hline \multirow[b]{2}{*}{ No } & \multirow[b]{2}{*}{ Aspek } & \multicolumn{3}{|c|}{ Kontrol } & \multicolumn{3}{|c|}{ Perlakuan } \\
\hline & & $\begin{array}{l}\text { Pre- } \\
\text { test }\end{array}$ & $\begin{array}{l}\text { Post- } \\
\text { test }\end{array}$ & $\delta$ & $\begin{array}{l}\text { Pre- } \\
\text { test }\end{array}$ & $\begin{array}{c}\text { Post- } \\
\text { test }\end{array}$ & $\delta$ \\
\hline 1 & Motivasi & 28.11 & 29.42 & 1.31 & 29.15 & 35.05 & 5.90 \\
\hline 2 & Bimbingan & 17.68 & 18.26 & 0.58 & 17.41 & 22.95 & 5.54 \\
\hline 3 & Pengawasan & 17.58 & 17.50 & -0.08 & 17.36 & 22.87 & 5.51 \\
\hline 4 & Fasilitas & 12.66 & 12.97 & 0.31 & 13.03 & 16.74 & 3.71 \\
\hline & Total & 77.03 & 78.16 & 1.13 & 76.95 & 97.61 & 20.66 \\
\hline
\end{tabular}

Dari rata-rata diatas dapat diketahui bahwa motivasi yang diberikan oleh orang tua rata-rata pada kelas kontrol pre test dari 13 instrumen diperoleh kenaikan 0.31 sedangkan pada kelas perlakuan diperoleh kenaikan pre test dan post-test sebesar 5.9 sehingga terdapat perbedaan sebesar 5.59. Ini berarti bahwa cara orang tua untuk memberikan dorongan pada anaknya sudah cukup baik khususnya pada kelas perlakuan. Hal tersebut meliputi penentuan cara belajar, pemberian pujian, hadiah, bantuan menyelesaikan PR, dan bantuan jawaban atas pertanyaan anaknya. Terdapat perbedaan antara kelas kontrol dan kelas perlakuan.

Rata-rata untuk bimbingan yang diberikan oleh orang tua pada kelas kontrol terdapat kenaikan 0.58, sedangkan pada kelas perlakuan mengalami kenaikan sebesar 5.54 sehingga terdapat perbedaan antara kelas kontrol dan kelas perlakuan untuk bimbingannya sebesar 4.96. Hal ini bahwa terjadi peningkatan meliputi pertanyaan orang tua tentang 
kegiatan di sekolah, menyuruh mengulang pelajaran, menemani belajar.

Untuk faktor pengawasan misalnya faktor mendampingi belajar anak, memeriksa hasil ulangan yang diperoleh terdapat perbedaan. Pada kelas kontrol terdapat penurunan 0.58 sedangkan kelas perlakuan terjadi kenaikan sebesar 5.51 sehingga terdpat perbedaan sebesar 6.09. Hal ini dimungkinkan pada kelas kontrol pengawasan yang diberikan orang tua cenderung kurang. Untuk faktor fasilitas misalnya meja belajar, alat-alat sekolah, penerangan, buku cetak terdapat perbedaan. Pada kelas kontrol terdapat kenaikan sebesar 1.13 sedangkan kelas perlakuan terjadi kenaikan sebesar 3.71 sehingga terdapat perbedaan sebesar 2.58. Hal ini dimungkinkan pada perlakuan setelah adanya pengayaan melalui pengarahan disekolah orang tua memiliki kesadaran untuk memberikan fasilitas kepada anaknya. Secara keseluruhan tingkat dukungan orang tua meliputi motivasi, bimbingan, pengawasan dan fasilitas yaitu pada kelas kontrol terjadi kenaikan sebesar 1.13 sedangkan pada kelas perlakuan mengalami peningkatan sebesar 20.66, terjadi perbedaan yang sangat signifikan yaitu sebesar 19.53. Hal tersebut wajar setah orang tuanya dipanggil disekolah timbul kesadaran untuk memberikan perhatian anaknya dalam makan dan gizinya, cara belajarnya, fasilitasnya untuk mendukung ketahan pangan melalui keluarga.

Pengujian dilakukan dengan membandingkan rata-rata hasil post-test setelah intervensi antara kelas kontrol dengan kelas perlakuan ternyata setelah diuji dengan uji beda $\mathrm{t}$, dukungan orang tua diperoleh $\mathrm{t}$ hitung sebesar 47.805 dan $t$ tabel 1.98 artinya bahwa tidak terdapat perbedaan yang signifikan antara kelas kontrol dengan kelas perlakuan.

\section{KESIMPULAN}

Terdapat perbedaan signifikan $(p<0.05)$ rata-rata tingkat pengetahuan pangan dan gizi siswa sesudah pengayaan antara kelas Kontrol (12.89) dan kelas perlakuan (15.03). Perbeda- an yang signifikan $(p<0.05)$ juga terdapat pada tingkat kebiasaan makan siswa sesudah pengayaan antara kelas Kontrol (30.65) dan kelas perlakuan (37.74).

Terdapat perbedaan yang signifikan pada tingkat kemampuan siswa dalam menyiapkan makanan khas Lampung Barat sesudah pengayaan antara kelas kontrol dan kelas perlakuan.

Tidak terdapat perbedaan signifikan IMT sesudah intervensi pengayaan antara kelas kontrol dan kelas perlakuan.

Terdapat perbedaan signifikan proses belajar mengajar kelompok kontrol dan perlakuan berupa tanggapan siswa tentang guru mulok dan kelas perlakuan.

Terdapat perbedaan yang signifikan pada tingkat dukungan orang tua terhadap siswa antara kelas kontrol dan kelas perlakuan.

\section{DAFTAR PUSTAKA}

Baliwati YF. 2004. Pangan dan Gizi. Rineka Cipta, Jakarta.

Kusharto CM. 1998 dalam Kartasapoetra dan Marsetyo. 2005. Ilmu Gizi - Korelasi Gizi, Kesehatan, dan Produktivitas Kerja. Rineka Cipta, Jakarta.

[Depkes] Departemen Kesehatan. 2000. Rencana Aksi Pangan dan Gizi Nasional 2001-2005. Pemerintah RI bekerjasama dengan WHO, Jakarta.

[Dirgizi Depkes] Direktorat Gizi Departemen Kesehatan RI. 1997. Daftar Komposisi Bahan Makanan. Direktorat Gizi, Departemen Kesehatan RI, Jakarta.

Depdiknas. 2008. Sistem Penilaian KTSP: Panduan Penyelenggaraan Pembelajaran Pengayaan. Departemen Pendidikan Nasional. Jakarta. 